\title{
Hvorfor leker vi fortsatt hviskeleken?
}

\author{
Pasientjournalene er blitt elektroniske, men formmessig er det fremdeles prosateksten \\ som dominerer. Mye kan gå tapt på veien når innholdet blir gjenfortalt i flere ledd. \\ Vi bør begynne å tenke nytt om organisering av journalmaterialet.
}

Det har gått ca. 20 år siden de første elektroniske journalsystemene ble innført i spesialisthelsetjenesten. I løpet av disse årene har datakraft og muligheter for lagring og håndtering av store datamengder utviklet seg enormt og er ikke lenger en begrensende faktor. Fortsatt er imidlertid hoveddelen i en elektronisk journal en lang (u)sammenhengende prosatekst. En tekst som er preget av gjenfortelling. Legen gjenforteller pasientens opplevelse av sykdommens symptomer, sin egen opplevelse av sykdomstegnene og sin egen og kollegers tolking og vurdering av den medisinske tilstanden. Henvisninger, tilsynsnotater og polikliniske vurderinger er eksempler på deler av journalen som ofte inneholder et sammendrag av vesentlig medisinsk informasjon om pasienten, gjenfortalt av forfattende lege.

Men hva skjer når vi leker hviskeleken? Jo, noen ganger kommer informasjonen (ordet) frem uendret til siste ledd i kjeden. Men andre ganger...

Kan det at hoveddelen av informasjonen i den medisinske journalen er organisert i prosaform, være en trussel mot pasientsikkerheten? Kunne vi organisert denne informasjonen på en annen måte?

Den viktigste kvalitetsparameter i helsetjenesten må være at behandlingen virker $\mathrm{og}$ at den gjør pasienten friskere. For å finne ut dette på individuell basis fungerer dagens journal brukbart, men å finne ut noe om dette på gruppenivå er langt vanskeligere. Vi har etter hvert opprettet en skog av kvalitets- og forskningsregistre nettopp for å svare på dette (enkle?) spørsmålet.

Kunne vi organisert den medisinske informasjonen i journalen på en annen og smartere måte enn som tekstdokumenter? Oppholdsinformasjon og laboratoriesvar er eksempler på informasjon i journalen som ikke er prosatekst. Kanskje kunne vi organisert hele journalen som en modulbasert database, slik at vi sikret at vesentlig informasjon ved de ulike kliniske tilstandene ble innhentet, registrert og formidlet korrekt.

Hvis vi i tillegg lot journalen tilhøre pasienten og ikke de ulike institusjonene og organiserte tilgangen i et nettverk, da ville ikke den samme informasjonen måtte overføres (hviskende) fra ledd til ledd i en uendelig kjede av helsearbeidere. Da kunne pasienten ha én medikamentliste, med informasjon om nåværende og tidligere medikamenter, blodtrykket kunne vært ført i én liste uavhengig av om det var målt på operasjonsstuen eller hos fastlegen. Da ville informasjon om pasientens tidligere sykdommer og kirurgiske inngrep kunne vært korrekt og lett tilgjengelig. Kvalitetsregistre kunne blitt overflødige ved at informasjon også på gruppenivå kunne hentes ut direkte fra journalene.

Det er lett å komme med innvendinger mot et slikt høytsvevende forslag, fra kostnader, datasikkerhet og problemer rundt eierskap av datasystemer, via vern av personlig og sensitiv informasjon, innsynsrett, administrasjon og programutvikling, til behovet for å formidle legens kliniske vurdering med nødvendige nyanser.

Jeg er imidlertid sikker på at alle disse innvendingene kan ivaretas og imøtegås. Det er teknikaliteter som kan løses - hvis vi våger å tenke høyt og nytt og fritt om vårt viktigste verktøy.

Journalen skal gi presis og korrekt overføring av informasjon mellom helsearbeidere, slik at pasienten kan få best mulig behandling. Gjør den det? Er informasjonsoverføringen blitt bedre ved dagens elektroniske journalsystemer? Eller leker vi fortsatt hviskeleken?

\section{Oppgitte interessekonflikter: Ingen}

\section{Anne Sofie Frøyshov Larsen \\ anne.sofie.larsen@so-hf.no \\ Radiologisk avdeling \\ Sykehuset Østfold \\ 1603 Fredrikstad}

Manuskriptet ble mottatt 20.1. 2010 og godkjent 11.2. 2010. Medisinsk redaktør Anne Kveim Lie.

\section{Farlige sykehusjournaler}

\author{
Legejournaler på sykehus føres på antikvarisk vis og med minimal kvalitetssikring. \\ De kan inneholde alvorlige feil, og pasientens sykdommer drukner i uvesentlige detaljer.
}

Legejournaler på sykehus skal hjelpe leger med å kunne stille en riktig diagnose for pasienter som har vært innlagt før. Dette forutsetter at det som står i journalen, er riktig. Ut fra egne erfaringer vet jeg at en sykehusjournal kan ha såpass graverende feil at det i verste fall kan stå om livet.

Journalen påføres ny informasjon hver gang man reinnlegges og blir undersøkt på mottakelsen. Alt som blir tilført journalen, blir senere betraktet som riktig, med minimal kvalitetskontroll av informasjonen. Er en uerfaren lege i tvil, kan han eller hun rådføre seg med en erfaren lege. Er den samme legen ikke i tvil, men tar feil, blir hans feilaktige konklusjoner stående som sannheter.
Svakheten med journalen er forst og fremst at den mangler metodikk for å se sykdommer i sammenheng. Legen legger inn beskrivelse av hva som er gjort av undersøkelser, med et vell av detaljer, men pasientens sykdom forsvinner i detaljene.

Dersom fremtidens elektroniske helsekort skal fungere, er det viktig å få med seg korrekte detaljer fra dagens sykehusjournaler videre. Det er ikke mulig slik journalene føres i dag.

Den eneste løsningen på dette er at journalføringen legges om. Den primære oppføringen må være den sykdom pasienten har vært behandlet for. Alle beskrivelser skal kun kunne tilordnes denne sykdommen.
Ved diagnose av ny sykdom skal tilføyelsen til hovedjournalen kun skje av ansvarlig lege, som selv må undersøke pasienten.

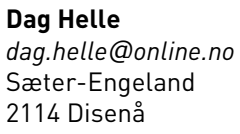

Oppgitte interessekonflikter: Ingen 